\title{
HUMAN STEM CELLS - SOURCES, SOURCING AND IN VITRO METHODS
}

\author{
Alicja Szubarga ${ }^{1}$, Marta Kamińska ${ }^{1}$, Wiktoria Kotlarz ${ }^{1}$, Stefan Malewski ${ }^{1}$, Wiktoria Zawada $^{1}$, \\ Matylda Kuczma ${ }^{1}$, Michal Jeseta ${ }^{2,3}$, Paweł Antosik ${ }^{4}$
}

\begin{abstract}
Stem cells are an important subject of research, and are increasingly used in the treatment of various diseases. Due to the development of advanced in vitro techniques, they have become an integral part of modern medicine. The sources of human stem cells are primarily bone marrow and adipose tissue, although non - embryonic stem cells are also scattered throughout the body. Notably, recent research has focused on stem cells found in the oral cavity, both in the dental pulp and oral mucosa. Furthermore, isolation of stem cells from umbilical cord blood is also becoming increasingly popular, while wharton's jelly and amniotic fluid also seem to be an interesting source of stem cells. The safety and efficacy of stem cells use can be established by animal studies, which are a key element of preclinical research. Mouse, rat and pig models allow for testing of stem cell therapies. Recent studies primarily use mesenchymal stem cells such as mouse - adipose derived mesenchymal stem cells and mouse and rat hematopoietic stem cells. Great hope for future therapies is the use of bioengineering to program cells into induced stem cells, which have the biggest ability for differentiation and transdifferentiation, which carries no risk of teratogenesis. Stem cells are used in many areas of medicine, especially in regenerative medicine, with a growing interest in orthopedics and in the treatment of heart failure. Mesenchymal stem cells are the most used stem cell type, which despite their limited ability to differentiate, give great therapeutic results, mainly due to their immunomodulating effect. Recent studies have even shown that the use of mesenchymal stem cells may be useful in the treatment of COVID-19. Moreover, Research on the use of mesenchymal stem cells in the treatment of Crohn's disease, acute-graft-versus-host disease and type I diabetes are also promising. The aim of the current review is to present and systematize current knowledge about stem cells, their use and related in vitro research.
\end{abstract}

Running title: Research and use of human stem cells

Keywords: Stem cell, mesenchymal stem cell, in vitro, stem cell therapy, animal model 


\section{Introduction}

Stem cells are undifferentiated or partially differentiated cells which can differentiate into specialised lineages and replenish their own population. The use of stem cells in medicine and veterinary medicine is an area of interest of many scientists. Stem cells were first described in 1961 as multipotent hematopoietic cells (HSCs) in a bone marrow of mice, capable of forming myeloerythroid colonies in the spleen [1]. Another crucial step in the understanding of stem cells was the isolation of human pluripotent stem cells (PSCs) by James A. Thomson. These cells were derived from the blastocyst and showed developmental potential to form the trophoblast and all three germ layers [2]. 8 years after the isolation of PSCs by Thomson, in 2006 Takahashi K and Yamanaka S. generated induced pluripotent cells (iPSCs). Based on 24 pluripotency - inducing genes of somatic cells, introduced into mouse embryonic fibroblasts (MEFs) by retroviral transduction, these researchers identified four basic transcription factors - Oct4, Sox2, Klf4 and c-Myc, that program somatic cells into pluripotent cells [3]. The discovery of the key factors determining pluripotency, offers significant opportunities in organ regeneration. Nowadays, there are more and more clinical trials using stem cells, especially iPSCs and mesenchymal stem cells, with related research focused on meeting the arising challenges. Notably, recent studies on COVID-19 therapy with bone marrow mesenchymal stem cells and human umbilical cord mesenchymal stem cells are promising [4,5].

Stem cells can be divided based on their differentiation potential. There are totipotent, pluripotent, multipotent and unipotent cells, found in both embryos and adult organism. The cells with highest potential for differentiation are embryonic stem cells (ESCs). They come from totipotent stem cells of the early embryo [2]. ESCs are pluripotent, capable of producing all structures derived from the three germ layers. The human ESC (hESC) is defined by the expression of several cell surface protein and transcription factors, like Oct-4, Nanog and Sox2, which are responsible for inhibition of genes that lead to differentiation, and maintenance of pluripotency [6]. With their enormous potential for differentiation, they are an attractive object to study. By inhibiting critical molecular pathways, expandable potential stem cells can be obtained in animal and human cells [7]. Studies on embryogenesis and attempts to control and induce it with appropriate cytokines offer promising therapeutic possibilities related to hESC transplantation $[8,9]$. Despite their enormous potential, ESCs are not widely used because of the danger of teratoma formation [10]. However, there are some promising studies on Very Small Embryonic - Like Stem Cells (VSELs), discovered in 2006 [11].

In the postnatal period there only adult stem cells are present in the organism, acting to regen- erate tissues. However, in contrast to ESCs, adult stem cells do not have high potential to differentiate. They can be multipotent, such as Mesenchymal Stem Cells (MSCs) or unipotent, like skin stem cells. MSCs deserve special attention, as they can differentiate into mesenchymal lineages, such as bone, cartilage, tendon, muscle, or fat [12]. They can be isolated from many tissues, such as bone marrow, adipose tissue [13] and perinatal tissues [14]. MSCs show a multilinear differentiation potential. They have a significant role in wound healing and tissue regeneration. They are the most used stem cells in therapies and tissue engineering, showing regenerative capacity in both human and animal models. The use of MSCs for therapeutic purposes requires in vitro culture, with their quality and differentiation influenced by many different factors during isolation and culture processes. MSC isolation methods and type of medium vary significantly, depending on where the material is taken and the type of cells in which MSCs are going to differentiate. Composing an ideal medium is difficult, therefore blood - based supplements are routinely used [15]. An important source of MSCs in the human body is the bone marrow and peripheral blood, which contains hematopoietic stem cells. They can also be obtained from umbilical cord blood and are currently the most used and understood MSCs.

According to U.S National Library of Medicine, there are more than eight thousand stem cells studies currently being conducted worldwide, based on both human and animal stem cells, most of which are MSCs. Acquisition of these cells does not raise any uncertainties with the ethics of such experiment. However, they have a limited ability to differentiate, which makes it increasingly important to devote more attention to iPSCs in experimental research.

Animal research is an inseparable part of stem cell studies. Stem cells derived from animals, despites some differences with human stem cells [16], shows similar gene expression responsible for pluripotency [17]. It is used in preclinical studies. Research on animals and isolated animal cells have initiated science of stem cells and they are still an indispensable element of it. The first ESCs were collected from mice and cultured in laboratory in 1981 by John Martin Evans, who was awarded the Nobel Prize for this achievement [18]. In vitro culturing of animal stem cells was a key tool for understanding the many aspects of cell biology. Particular attention is currently paid enabling the use of stem cells in the treatment of diseases of nervous system. Many of these studies are in the preclinical phase, using animal mostly rat and mice $[19,20]$. In vitro animal models allow for control environmental conditions that directly affect cell differentiation and ensure repeatability of the test. The types of stem cells used in experimental animal model studies are Adipose-derived MSCs and bone marrow MSCs. Human 
stem cells can also be injected into animals to evaluate the effects of a therapy [21]. However, animals are also used to investigate the safety of stem cells [22].

In vitro research and culture allow to use different types of stem cells for therapeutic purposes even after a small number of stem cells has been collected or induced. It is used in cell and tissue bioengineering, e.g. for treatment of burns by transplanting the cultured transgenic epidermis with an appropriate amount of stem cells [23]. Research using hydrogels as a substrate for the culture of cartilage is also promising [24]. Furthermore, bioprinting is also an important biotechnological achievement. It is a relatively new technology that allows tissue reconstruction using stem cells, allowing for of e.g. cultures of bone tissue [25], as well as treatment of heart failure and cultures of corneal tissue [26]. These are just a few examples of the possibilities that stem cells bioengineering presents in modern medicine.

\section{Morphological and physiological characteristics of stem cells}

Stem cells have a specific morphology and physiology, which allows them to maintain the ability for self-renewal and multidirectional differentiation [27]. These attributes enable them to sustain morphogenetic processes and tissue homeostasis. Many research groups dedicated significant work to learn about stem cells' structure and molecular or chemical signatures. Briggs and King conducted researche involving transplanting nuclei from advanced blastula cells into enucleated eggs of frogs in 1952 and 1956. They were the first to conduct a successful nuclear transplantation with amphibian embryos [28]. Evans and Kafman, as well as Martin, in 1981 for the first time isolated pluripotent stem cells with stable karyotype from a mouse blastocyst $[18,29]$. In next years it was proved that the changes taking place in the nucleus are reversible and, e.g. nuclei transplanted from keratinized skin cells of adult frogs implanted into the oocyte is able to develop into an embryo [30]. In the following years, the structure and processes that make stem cells unique compared to other cells in the body began to be explored. It has been proven that some proteins can influence the activity of others, as their decreased or increased expression determine the further fate of the cell [31-33].

Stem cells can be divided into 5 groups: totipotent, pluripotent, multipotent, oligopotent and unipotent. Totipotent cells can form embryonic and extraembryonic tissues, with their activity sufficient to form the entire organism. In turn, pluripotent cells only form embryonic tissues of ectodermal, endodermal and mesodermal origin. Furthermore, multipotent cells have the ability to form multiple lineages derived from a single germ layer. The last two types of cells have the most limited differentiation potential. Oligopotent stem cells are able to self-renew and form two or more lineages within a specific tissue, while unipotent stem cells can self-renew and form a single lineage [27, 34].

Stem cell population is a heterogeneous group, made up of mitotically active and mitotically inactive cells. This feature of stem cells is influenced by internal or environmental cues [35].

Cells can divide symmetrically and asymmetrically. They do not commit to a single model of cell division but are able to switch modes during consecutive cycles [36]. Each stem cell faces two types of decisions: division or senescence and proliferation or differentiation. Which cell divides and when, as well as what division type it undergoes must be subject to feedback loops, to assure that the populations sizes do not deviate from the physiologically desired levels as a result of random fluctuations [37].

Microenvironment and its signals, which regulate maintenance and regeneration of tissues, are referred to as the stem cell niche. This structure contains components of the extracellular matrix, growth factors, neurotransmitters, hormones and receptors located on adjacent cells. The ECM consists of different elements, which are intertwined and can directly influence stem cell biology [38].

Mechanical and morphological profiles, together with genetic and epigenetic factors, determine stem cell phenotypes. Cytoplasmic mechanisms in perinuclear regions can distinguish different stem cell types and are influenced by both biochemical and morphological inputs [39]. Human MSCs, belonging to the group of multipotent cells, are fusiform and have nuclei of large size, which decreases during differentiation. When the nucleus remodels, the expression of the main LMNA envelope protein increases and the roundness of the nucleus decreases [40]. Changes in the MSC nucleus during differentiation processes have been characterized on many levels [41].

Membrane proteins, particularly of the plasmalemma, perform an important function in defining the unique characteristics of stem cells and controlling their survival and death. For example, the dominant integrin heterodimer of human pluripotent stem cells is $\alpha 6 \beta 1$. Undifferentiated hPSCs are characterised by the majority of integrins in an inactive state, but ready to be activated. These integrins affect the activity of focal adhesion kinase, which is associated with pluripotency transcription factors Oct4 and Sox2 and influences hPSC differentiation [42]. Mesenchymal stem cells also express CD105 and CD166, as well as Stro-1. [43]. These cell-specific surface proteins enable their phenotyping. 
Stem cells also have a specific metabolism, as can be seen on the example of mesenchymal stem cells. These cells exhibit a mixed metabolism, utilising both glycolysis and oxidative phosphorylation for ATP generation. MSCs exhibit a high level of glycolytic metabolism, with the mitochondrial contribution of slightly less than $30 \%$, due to the decreased activity caused by mitochondrial membrane leak [44]. Stem cells are able to adapt their metabolism depending on the availability of nutrients and metabolites, with some cells fully resistant to adverse conditions, such as ischemia, for even 6 hours [45]. Properties such as proliferation, clonogenicity, cell cycle, multipotency and autophagic flux are dependent on oxygen concentration both at early and late passages. Stem cell expansion at low oxygen concentration exhibits increased proliferation capability, high autophagic flux and a preserved expression of the specific markers $[46,47]$.

In the context of stem cells, it is worth to mention the process of autophagy. It plays critical roles in stem cell quiescence, activation, differentiation, and self-renewal. Researches have shown that autophagy has essential function in maintaining HSC stemness and regenerative potential [48]. The importance of this process in embryonic stem cells has also been emphasized, partly to fulfil the energy requirements for cell remodelling, metabolic and proteostatic changes, as well as for the engulfment and clearance of apoptotic cells and the regulation of key morphogen signalling pathways of neurogenesis $[49,50]$.

\section{Human stem cell sources Embryonic stem cells}

Stem-cell therapies are fast becoming a key instrument in treating many diseases, due to a large amount of trials to implement them in clinical setting. A milestone in this field research was achieved when mice ICMs were isolated by Martin et al. in 1918 and formed a teratocarcinoma when injected subcutaneously into host [29]. Many authors were inspired by this accomplishment, which contributed to new attempts in this area. This resulted in a proof that cells present in teratocarcinomas are pluripotent and capable of differentiating into at least two lineages [51]. Another vital step was made when Thomson and associates, who isolated 14 inner cell masses from five separate human embryos in blastocyst stage. These five ES cell lines maintained a potential to differentiate into all three embryonic germ layers [2]. Recent studies suggest that naive hESCs can be converted into cells with a transcriptome and methylome similar to human trophoblast stem cells (hTSCs). This allowed core placental gene reactivation and placenta-like methylome acquisition [52].

\section{Non-embryonic (adult) stem cells}

HSCs constitute $1 \%$ of bone marrow mononuclear cells (BMMNCs) [53], with their transplantation being a common procedure intended to treat many diseases such as leukemia, lymphoma or myeloma. There have also been numerous studies to investigate whether there are different types of stem cells in bone marrow, which could be used in the stemcell therapy. For example, endothelial progenitor cells (EPCs) were isolated from bone marrow to treat ischemic stroke through EPCs transplantation [54]. Moreover, there are stem cells in bone marrow and peripheral blood which may play more significant role in vasculogenesis than EPCs. It was proved that the VSELs exhibit endothelial phenotype in vitro in the presence of VEGF-B, as well as in vivo in Matrigel implants [55].

It is now well established that adipose-derived mesenchymal stem cells (AMSCs) can be used in plenty of therapeutic procedures. Abdominal fat tissue, which can be collected by lipoaspiration, may be considered as a crucial source of AMSCs. Therefore, designing the scaffold-free three-dimensional (3D) grafts made of these cells is increasingly plausible [56].

A large and growing body of literature has also investigated the relevance of epidermal stem cells, which can be divided into dermal-derived neural crest stem cells, MSC-like dermal stem cells and dermal hematopoietic cells [57]. Furthermore, in other studies self-renewal and multipotency of two different types of stem cells in each hair follicle were revealed. These cells formed epidermis and hair when grafted into mice [58].

Several attempts have been made to prove that limbal epithelium can be considered as an essential source of stem cells. The surgical techniques of limbal transplantation improved over time, with this procedure requiring less donor tissue not needing a specialist laboratory to harvest cells [59].

In recent years, there has been an increasing amount of literature focusing on stem cells, which can be found in human oral cavity. For example, dental pulp stem cell (DPSC) isolation demonstrated that these cells have the ability to form dentin and pulp-like complex [60]. This discovery contributed to many transplantation trials, which revealed that mobilized dental pulp stem cells (MDPSCs) have therapeutic potential to regenerate the pulp in pulpitis [61]. Other authors investigated the presence of human stem cells in periodontal ligament and showed their ability to differentiate into cementoblast-like cells, adipocytes, and collagen-forming cells. When injected into immunocompromised rodents, these cells contributed to periodontal tissue repair [62]. Human mucosa also seems to be a promising source of stem cells for autologous transplantation therapies. Although these struc- 
tures were isolated from oral mucosal epithelium or even from adult olfactory mucosa, many clinical trials are needed before they will be used in common treatment procedures [63]. Moreover, recent studies also highlight that stem cells can be easily collected from voided urine. Human-urine-derived stem cells (USCs) are capable of differentiating into osteogenic, chondrogenic, adipogenic, and neurogenic lineages [64].

\section{Stem cells in fetal structures}

An easily accessible source of stem cells, which can be used for autologous transplantations, has been a subject of scientists' interest for years. Studies analyzing if there are MSCs in human placenta seem promising, with one of the first trials revealing the presence of these cells and their ease of isolation from the mentioned structure. Moreover, PMSCs were cultured using a very simple technique, without characteristic morphological changes in medium [65]. Another source of stem cells, which can be obtained non-invasively, may be the human umbilical cord. These cells seem to have a great potential not only to differentiate into many structures but also regulate monocyte secretome [66]. Isolating cells from Wharton's jelly may also be a simple method of obtaining MSCs. It has been suggested that they can be easily harvested and have properties to initiate the process of wound healing [67]. Recently, there have been several reports showing the presence of stem cells in amniotic fluid, with isolated cells capable of differentiating into multiple lineages such as hepatic, neuronal, myogenic, adipogenic, osteogenic and endothelial. Additionally, neuronal lineage presented an ability to secrete neurotransmitter L-glutamate and express G-protein-gated rectifying potassium channels [68].

\section{Types of stem cells used in an experimental study in animal models \\ Adipose-Derived Mesenchymal Stem Cells}

Mouse adipose-derived mesenchymal stem cells (mADMSCs) have been used in the therapy of liver fibrosis (LF) induced by carbon tetrachloride (CCl4) in a mouse model. mADMSCs were injected into the tail vein once a week for 2 weeks. Moreover, mADMSCs with antioxidant preconditioning could improve restoration of liver function and expand the intrahepatic transplantation of mADMSCs [69].Furthemore, mADMSCs have been used in treatment of the mouse model of chronic ovalbumin-sensitized asthma, through endotracheal administration at $21^{\text {st }}$ day of disease. Therapy with mADMSCs could moderate inflammation of the respiratory tract, palliate airway excessive responsive and expand airway remodelling [70]. Furthemore, mADMSCs have been used as a therapy in cutaneous leishmaniasis in a mouse model, through hypodermic injection at the infection surface. The administration of mADM-
SCs was repeated 4 times more, once a week until $28^{\text {th }}$ day after infection. The mADMSCs could not remove Leishmania major but briefly facilitated intensification of immune reaction against $L$. major by upregulating the inflammatory reaction and slowing propagation of infectants [71].

Rat adipose-derived mesenchymal stem cells (rADMSCs) have been used as a therapy in monocrotaline-induced pulmonary arterial hypertension in a rat model. rADMSCs were injected into the jugular vein on the $14^{\text {th }}$ day of disease. After 2 weeks, lung vascular rebuilding was mitigated, which expanded hemodynamics [72]. Moreover, undifferentiated rADMSCs (u-rADMSCs) have been used in therapy following partial hepatectomy in a rat model. u-rADMSCs were administered via the portal vein or into the parenchyma immediately after liver resection. They could stimulate the liver recovery and moderate the histopathological liver insult by concurrently expanding the expression of specific regeneration-genes for liver, regardless of their number and the way of transplantation [73].

Bama pig adipose-derived mesenchymal stem cells (BpADMSCs) have been used in the therapy of LF caused by $\mathrm{CCl} 4$ in a mouse model. After 4 weeks of treating the mice with CCl4, BpADMSCs were administered through the portal vein. This improved liver regeneration, as well as reduced necrosis, inflammation and fibrosis [74].

Human adipose-derived mesenchymal stem cells (hADMSCs) associated with a scaffold of collagen sponge have been used to construct a full-thickness skin graft in a mouse model. The application of full thickness graft of tissue-engineered skin improved wound treatment and encouraged injure repair at soon as 7 days after the surgery [75].

\section{Bone Marrow Mesenchymal Stem Cells}

Mouse bone marrow mesenchymal stem cells (mBM-MSCs) have been used in the therapy of mouse oxygen-induced retinopathy model by injection into the vitreous body. Observation for 10 days after transplantation showed that the mBM-MSCs could suppress neovascularization and present a preventive effect on retinopathy induced by oxygen. Moreover, the mBM-MSCs could migrate to the site of damage on retina, reduce the apoptosis of retinal cells and expand the density of retinal vessels [76]. Furthermore, microRNA-9-5p modified mBM-MSCs (miR-9-5p-m-mBM-MSCs) have been used in bone cancer pain therapy in a mouse model. The miR-95p-m-mBM-MSCs were infused through a catheter placed in the subscleral region each day from 2 days before implantation of murine sarcoma cells until $21^{\text {st }}$ day after surgery. miR-9-5p-m-mBM-MSCs could mitigate pain caused by bone cancer by regulating inflammation of the nervous tissue in the central nervous system [77]. The mBM-MSCs have been induced for endothelial differentiation and used as a therapy 
in hindlimb ischemia in a mouse model. The endothelial-like cells (ECs) were injected into the paracentral thigh of the gastrocnemius muscle in 3 various places within 1 day after the model surgery. The ECs could increase therapeutic result of angiogenesis and have stronger ability in vascular creation [78].

Rat bone marrow mesenchymal stem cells (rBMMSCs) have been used in the therapy of LF induced by $\mathrm{CCl} 4$ in a rat model. The rBM-MSCs were injected via the penile vein after one month treatment with $\mathrm{CCl} 4$ in two doses, the second one week after the first. The rBM-MSCs were able to reconstruct liver architecture and soften $\mathrm{CCl} 4$ induced LF [79]. The rBM-MSCs have been used in healing of peripheral nerve damage and restoring limb function in a rat model. The rBM-MSCs injections were administered at the nerve surfaces needing repair during the surgery. After the procedure, the rBM-MSCs were injected in the dorsal penile vein and readministered for 3 weeks with one-week interspace between doses. The rBM-MSCs could improve restoration of extremity function and promote the nerve recovery [80]. The rBM-MSCs have been used in diabetic ischemic wound treatment on the dorsal region of foot of noninsulin-dependent diabetes mellitus in a rat model. The rBM-MSCs were injected locally, intracutaneously or by infusion through the left femoral vein, instantly after the wound was created. After 14 days, both local and systemic administration of rBM-MSCs stimulated the wound treatment process. Moreover, the systemic infusion could remedy the injured tissue and mitigate hyperglycemia [81].

\section{Other Mesenchymal Stem Cells}

The transplantation of human umbilical cord mesenchymal stem cells (hUC-MSCs) has been used in a treatment of allergic rhinitis in a mouse model. The hUC-MSCs were injected several times at specifies intervals, intraperitoneally or into the tail vein. The hUC-MSCs migrated to the nasal cavity and suppressed the allergic reaction. However, tail vein injection was more effective in this therapy [82]. Furthermore, hUC-MSCs have been used in the therapy of collagen-induces arthritis in a rat model. The injection of hUC-MSCs was administered through the tail vein on $10^{\text {th }}$ day, decreasing the injury of bone in the ankle joints after 28 days and exhibiting therapeutic effect through modulation of intercommunication among gut flora and host resistance via the aryl hydrocarbon receptor [83]. Moreover, the freshly defrosted hUC-MSCs (D-hUC-MSCs) and cultured hUC-MSCs (C-hUC-MSCs) were administered in a case of full-thickness flaw of rotator cuff tendon in a rat model. The D-hUC-MSCs or C-hUCMSCs were injected in two separated doses into the tendon approximal at both sides of the injury, which resulted in regeneration of tendons comparable to C-hUC-MSCs [84].
Human chorionic plate-derived mesenchymal stem cells (hCPDMSCs) have been used in therapy of cyclophosphamide-induced premature ovarian insufficiency in a mouse model. The hCPDMSCs were administered by the tail vein one time per week for 4 weeks. The transplantation of hCPDMSCs improved the function of ovary and enable follicle and oocyte growth [85].

Gingival mesenchymal stem cells (GMSCs) have been obtained from human fetal gingival tissue and used in gingival defect therapy in a rat model. The GMSCs were grafted into the injury area of the gingiva 6 days after excision of the tissue around the mandibular incisor. The GMSCs were able to reduce the imperfection area 1 week after grafting, also recreating the color and morphology of local tissue, resembling natural gingiva, 3 weeks after transplantation [86].

Human mesenchymal stem cells isolated from Wharton's jelly (hW-MSCs) have been induced to endothelial differentiation and used as a therapy in aged diabetic rat model. The trans-differentiated ECs (tdECs) were injected by the tail vein 6 weeks after diabetes verification. The tdECs derived from hW-MSCs could counter the dysfunction of endothelium, inflammation and oxygen-induced stress [87].

Stem cells from human exfoliated deciduous teeth (SHED) combined with a scaffold of hydroxyapatite have been grafted to into a defect of alveolar bone in a rat model. The SHED with hydroxyapatite scaffold could be an efficient agent in the regeneration of defects of alveolar bone by raising osteoprotegerin and decreasing expression of receptor activator of nuclear factor-kappa B ligand [88].

\section{Stem cell bioengineering}

The research on embryonic stem cells started in the 1950s. In 1954, spontaneous testicular teratoma was discovered in mouse strain 129 . This discovery started experimental work on teratomas and teratocarcinomas. Leroy C. Stevens and C.C. Little proved that teratomas are composed of many types of embryonic and adult tissues that are not typically found in testis. They transplanted fifteen spontaneous teratomas and one of these developed into a transplantable tumour which consisted of undifferentiated cells with the ability to grow subcutaneously and in ascitic fluid [89].

Another important study showed the multipotentiality of single embryonal carcinoma cells. The study involved the transplant of over 1700 single cell grafts. As a result of transplantation, 44 clonal lines were obtained, 43 of which were teratocarcinomas composed of different well-differentiated somatic tissues [90].

Interest in this subject increased in 1970s, due to improvements of knowledge on mammalian development and cell differentiation. Martin and Evans 
subcloned mass cultures of pluripotent teratocarcinoma cell lines, which led to the discovery of the cells with large nuclei and dark cytoplasm that grew in the form of small colonies. These cells could proliferate and produce teratocarcinomas after subcutaneous injection, and became known as embryonal carcinoma cells $[91,92]$.

Mouse and human embryonal carcinoma cell lines were identified by specific markers, characteristic for the embryonal carcinoma cell and disappearing during differentiation. The first marker was the alkaline phosphatase enzyme. Later, thanks to the development of the monoclonal antibodies, several specific proteins were discovered. The antibodies detecting mouse embryonal carcinoma cells react with the Forssman antigen and stage-specific embryonic antigen 1 (SSEA1). Furthermore, it turned out that mouse embryonal carcinoma cells express SSEA3 and SSEA4 during differentiation. On the other hand, human embryonal carcinoma cells express SSEA3 and SSEA4, and SSEA1 only during differentiation [92].

Similarities between mouse embryonal carcinoma cells and the cells of early embryos were also noticed. This and the fact that teratocarcinomas can be derived from embryos led to further research on whether embryonal carcinoma cells retain their embryonic nature. Teratocarcinoma cells were transferred into a blastocyst and, after the blastocyst development, small colonies of the transferred cells were visible in the embryo, some of which persisted into the adult [93].

The knowledge gained by studying teratocarcinomas and embryonal carcinoma cells resulted in the development of embryonic stem cells (ES). In 1981 Evans, Kaufman and Martin discovered that the cells from early mouse embryos that are exposed to the same environment can stop development and continue to multiply [94].

Human embryonic stem cells (hES) were isolated from the human blastocyst for the first time in 1998. These cells could form trophoblast and derivatives of all three embryonic germ layers after 4-5 months of proliferation in vitro [2]. In the same year, hES were obtained from human embryonic germ cells (hEG), isolated from gonadal ridges and mesenteries of 5-9-week-old human fetuses from abortions performed for health reasons [95]. These procedures of obtaining hES lead to the destruction of the embryo, which causes serious ethical problems. Therefore, attempts were made to invent other techniques for derivation of ES cells. In 2006, hES cells were derived from single blastomeres [96], with this procedure not disturbing the further development of the embryo. Other sources of hES cells turned out to be arrested embryos [97] and parthenogenetic blastocysts [98].

The next achievement was the induction of pluripotent stem cells from differentiated somatic cells.
These cells were named induced Pluripotent Stem cells. The first iPS cells were obtained from mouse embryonic and adult fibroblast cultures by introducing specific factors - Oct3/4, Sox2, c-Myc and Klf4 [3]. A year later, the same experiment was performed using human somatic cells, which proved that iPS cells can be generated from adult human fibroblasts [3].

There are three main factors responsible for maintenance of pluripotency of ES cells: 0ct3/4, Nanog and Sox2. These factors create the regulatory network to control each other's expression levels [99]. Oct4, Nanog and FoxD3 form a negative feedback loop in order to maintain their expression in pluripotent ES cells [100]. Oct3/4 and Sox2 genes are involved in a synthesis of transcription factors such as UTF-1, REX-1/Zfp-42, telomerase reverse transcriptase (TERT) and telomeric repeat binding factor 1 and 2 (TERF1, TERF2).

Reprogramming of cells has great potential for medical applications. However, iPS cell form teratoma when injected into tissues. Hence, the process of transdifferentiation seems to be an interesting solution. Transdifferentiation is a transformation of one specialized cell into another. Pluripotent cells don't take part in this process, so it doesn't carry the risk of teratomagenesis [101]. An example of transdifferentiation is the study from 2008, which involved reprogramming of adult mice pancreatic exocrine cells to beta-cells using three transcription factors - Neurog3, Pdx1 and Mafa [102]. Another finding showed that human fibroblast can be reprogrammed to cardiac-like myocytes. This procedure included inducing expression of cardiac markers in neonatal and adult human fibroblasts [103].

All of these studies indicate that bioengineering methods using cells can have great application in clinical medicine.

\section{In vitro research on stem cells and their use in clinical trials}

Stem cells are increasingly used nowadays in clinical practice due to their unique properties. They are employed in studies in the field of regenerative medicine, orthopedics, cardiology, neurology and many others.

The employment of stem cells in regenerative medicine enables very effective treatment and satisfactory results. Gjerde et al., in their trial, used bone marrow- derived MSCs to induce regeneration of mandibular bone defect, which is a less invasive method than autologous bone grafting, a current gold standard procedure. BCP (biphasic calcium phosphate) granules, used as scaffold material, with MSC's attached, were introduced into the operation site. There was noticeable increase in both volume and width of the alveolar ridge. Moreover, all patients were pleased with the clinical outcome of the procedure, which was yet another crucial benefit 
of this method [104]. Stem cells have also proved useful in skin wound healing process, providing better aesthetic outcomes, but most importantly solving the problem of ineffective vascularization. For this purpose, Samberg et al. applied combination of PEGylated PRP (platelet rich plasma) hydrogel and ASCs (adipose-derived stem cells). High concentration of growth factors contained in platelets and fibrin-made scaffold created optimal conditions for effective angiogenesis and new tissue's growth. Using hydrogel turned out to be an effective way to maintain moist environment within the wound. This approach was tested in vitro and on an animal model. The study showed that applying this method resulted in greater blood vessel density in PRP + ASCs group than in the others (without PRP or ASCs). While amendment of other parameters, such as faster wound closure, was not observed, it is a potentially efficient procedure that could be considered when it comes to an improvement of wound healing [105]. In other study allogenic ASCs were applied in a form of hydrogel-based sheets to patients with diabetic foot ulcers. In the treatment group, wounds healed faster and more patients achieved complete wound closure compared to the control group [106]. Stem cells could also be used for regeneration and preservation in reproductive medicine. Jia et al. used human umbilical cord stem cell conditioned medium (hUC-MSC-CM) to reduce cryoinjury in frozenthawed human OCTs (ovarian cortical tissues). In the hUC-MSC-CM group, neoangiogenesis was increased and follicular apoptosis was decreased in comparison with the SF-CM (serum- free culture medium) group. This effect is in part assigned to hUC-MSC's paracrine activity, with growth factors and cytokines acting as protective factors. This method may be used in the future as an effective way to reduce ischemic damage and apoptosis of follicles in OCTs and, as a result, to avert fertility loss [107].

Stem cells are becoming increasingly interesting, not just when it comes to regenerative medicine. Nowadays, SCs are also often employed in orthopedics. Gupta et al. used bone marrow-derived, cultured, pooled, allogenic mesenchymal stromal cells (Stempeucel $®$ ) to treat osteoarthritis, which is a type of joint disease involving degeneration of joint cartilage. Intra- articular injection of Stempeucel ${ }^{\circledR}+$ HA resulted in significant pain reduction on an animal model in comparison with a group that was treated only with HA, with improvement in cartilage repair also observed [108]. In other study, Lamo - Espinosa et al. applied intra-articular injection of autologous bone marrow MSCs to patients with osteoarthritis. Those who were given BM-MSC noticed major pain reduction, while others who were given HA did not report any significant changes. There was also an improvement in the range of knee motion in the group who had BM-MSC injec- tion (especially- higher dose). These results suggest that therapies using MSCs are safe and may be used more often in the future of orthopedics [109].

Nowadays, an increasing number of methods using stem cells are being tested as a treatment for patients with heart failure (HF) with low ejection fraction. Intravenous infusion of umbilical cord mesenchymal stem cells (UC-MSC) was used by Bartolucci et al. as a therapy for patients with HF. Improvement in left ventricular ejection fraction (LVEF) and quality of life was observed in UC-MSC group [110]. In other study, Soetisna et al. used autologous CD133+ bone marrow stem cells to examine their impact on cardiac function. Transepicardial and transseptal implantation of said cells was performed on patients with coronary heart disease with low ejection fraction during coronary artery bypass grafting. There was a significant increase in LVEF and decrease in WMSI (wall motion score index) in CD133+ group compared with control groups. Improvement was also noticed in scar size proportion in CD133+ group. These results suggest that this treatment may be applied for better cardiac repair and patient's better life quality [111].

Stem cells have been also used by $\mathrm{Oh}$ et al., who applied autologous bone marrow-derived mesenchymal stromal cells to patients with amyotrophic lateral sclerosis (ALS). MSCs were administered intrathecally in two succeeding injections. The decline in ASLFRS-R score was not accelerated, furthermore it was more gradual during the follow-up in comparison with the lead-in period. Moreover, after MSC injection IL-10 and TGF- $\beta$ levels were elevated, while MCP-1 level was decreased, which suggests that this treatment may be beneficial for ALS patients' immune response [112]. Similar results were achieved in other clinical study with MSC application in ALS patients [113], which indicates that MSC administration could be an effective ALS treatment in the future.

Pang et al. used allogenic bone marrow-derived mesenchymal stromal cells expanded in vitro as a possible approach of treatment for patients with aplastic anemia (AA). MSC's time to response (TTR) was significantly shorter than TTR of immunosuppressive factors that are used in AA therapy. The improvement of leukocytic and megakaryocytic lineage was also observed - after the treatment white blood cell counts, platelet counts, hemoglobin counts and Treg percentages were considerably higher in comparison to the baseline. This suggests that while the treatment is potentially a good solution for patients suffering from AA, it requires further evaluation [114]. Peripheral blood stem cell (PBSC) transplantation can be used in the treatment of AA as well. In their trial, Purev et al. used PBSC allograft containing CD34+ cells and non-mobilized T-cells in lower dose than in unmanipulated 
PBSC. This approach also resulted in neutrophil and platelet recovery. What is more, the risk of acute and chronic GVHD was decreased compared to unmanipulated PBSC [115].

In a recent study, Sengupta et al. attempted to treat patients with severe COVID-19 with exosomes (ExoFlo) derived from BM-MSC. Patients' oxygenation improved after administration suggesting that ExoFlo may prevent oxygenation's deterioration, and consequently the necessity of mechanical ventilation. Inflammatory markers (CRP, ferritin, D-dimer) were decreased and there was a major improvement in neutrophilia and lymphopenia observed as well [5]. In turn, Leng et al. transplanted MSCs to patients with COVID-19 pneumonia. Patients' clinical status improved significantly after MSC administration- CRP, TNF- $\alpha$ decreased, whereas IL-10 and VEGF rose, which promoted patients' recovery. MSCs are known to have immunomodulatory effect; therefore, they could prevent cytokine storm which is a highly dangerous incident during COVID-19. This therapy turned out to be particularly effective for critically severe patients [116].

Dhere et al. used autologous noncryopreserved BM-MSC as a novel therapy for patients with moderate to severe Crohn's disease. This method turned out to be safe and well tolerated by participants. 5/11 of enrolled patients responded to the treatment and $6 / 11$ did not. What is more, allogenic MSCs would pose a risk of immune rejection, thus application of autologous MSCs was a safer solution. The results are promising, but estimation of this method's efficacy requires further research [117]. In other clinical trial Zhang et al. reported that UC-MSC infusion is a potentially effective treatment for patients with Crohn's disease. The results showed noticeable improvement in patients' clinical status. Crohn's disease activity index declined as well as Harvey-Bradshaw index and corticosteroid dosage a year after the treatment. It was also noticed that UC-MSC administration was safe in general, with only mild side effects such as fever occurring. However, long-term effect and mechanism of action of UC-MSC treatment is not known and is yet to be studied [118].

MSCs were used by Zhao et al. to treat patients with acute graft-versus-host disease (GVHD) after hematopoietic stem cell transplantation. Majority of patients responded to the treatment which is a promising result that is ascribable to MSC's immunomodulatory activity. Patients from MSC group presented an increased Treg count and decreased incidence of chronic GVHD compared to the control group. There was also thymic function improvement noted, evaluated by observing changes in sjTREC (signal joint T cell-receptor excision DNA circle) levels. Due to these mechanisms MSCs might reduce severity of chronic GVHD without increased risk of infections or tumor relapse [119]. In other trial, single-dose MSCs were applied to patients before haploidentical peripheral blood stem cell transplantation (PBST). This treatment resulted in a decline of incidence of severe acute GVHD in MSC group compared to the control group [120].

Carlsson et al., in their study, researched safety and efficacy of autologous MSCs applied to patients with new-onset type 1 diabetes. In MSC group, C-peptide response to mixed meal tolerance test did not decrease. Moreover, in some cases it was elevated with no side effects reported. The results suggest that this treatment may be an effective way to preserve $\beta$-cell function, although it requires further examination [121]. In other study, issue of autoimmune activity of T-cells in type 1 diabetes was addressed through the use of use of Stem Cell Educator (SCE) which is a therapy that employs human multipotent cord-blood stem cells (CB-SC). Lymphocytes separated from patient's blood are transported to the SCE device and after interaction with CB-SC educated lymphocytes are returned to patient's bloodstream. The outcome indicates that this therapy modifies patient's immunological response and helps to restore immune system balance [122].

\section{Conclusions}

The use of stem cells gives hope for the development of medicine and effective treatment of many diseases. Promising research on the use of mesenchymal stem cells concerns the treatment of COVID-19, which responds to the current problems during the SARS-CoV-2 pandemic. The clinical condition of patients improved significantly after the administration of stem cells, especially in critically ill patients. Treatment of type I diabetes, Crohn's disease or heart failure may become a common and effective solution in the fight against these diseases in the future. The advancement of in vitro research using animal stem cells is making enormous progress in understanding the capabilities of stem cells. Mouse, rat and pig models allow testing stem cell therapies due to the similarity of human and animal stem cells which, despite some differences, show expression of the same key genes for pluripotency. The widespread use of mesenchymal stem cells in animal models in research on the treatment of retinopathy, allergic rhinitis and many other diseases shows the multitude of possibilities offered using stem cells in medicine. It seems particularly important to look for solution enabling the use of pluripotent cells and cell transduction. Cell bioengineering gives great opportunities, but many solutions require additional research related to the effectiveness and safety of such therapies. Stem cells are the part of modern medicine and may become a key element in the future therapies. 


\section{Ethical approval}

The conducted research is not related to either human or animal use.

\section{Acknowledgments}

Not applicable.

\section{Corresponding author}

Paweł Antosik, Department of Veterinary Surgery, Institute of Veterinary Medicine, Nicolaus Copernicus University in Toruń, 7 Gagarina St., 87-100 Toruń, Poland, tel. +48 5661122 31, +48 5661130 93, e-mail: pantosik@umk.pl.

\section{Conflict of interest statement}

The authors declare they have no conflict of interest.

\section{References}

1. Till J, McCulloch EA. A direct measurement of the radiation sensitivity of normal mouse bone marrow cells. Radiat Res. 1961;14:213-22.

2. Thomson JA, Itskovitz-Eldor J, Shapiro SS, Waknitz MA, Swiergiel JJ, Marshall VS, Jones JM. Embryonic stem cell lines derived from human blastocysts. Science. 1998 Nov 6;282(5391):1145-7. DOI: 10.1126/science.282.5391.1145. Erratum in: Science 1998;282(5395):1827.

3. Takahashi K, Yamanaka S. Induction of pluripotent stem cells from mouse embryonic and adult fibroblast cultures by defined factors. Cell. 2006;126(4):663-76. DOI: 10.1016/j.cell.2006.07.024.

4. Shu L, Niu C, Li R, Huang T, Wang Y, Huang M, Ji N, Zheng Y, Chen X, Shi L, Wu M, Deng K, Wei J, Wang X, Cao Y, Yan J, Feng G. Treatment of severe COVID-19 with human umbilical cord mesenchymal stem cells. Stem Cell Res Ther. 2020;11(1):361. DOI: 10.1186/s13287-020-01875-5.

5. Sengupta V, Sengupta S, Lazo A, Woods P, Nolan A, Bremer N. Exosomes Derived from Bone Marrow Mesenchymal Stem Cells as Treatment for Severe COVID-19. Stem Cells Dev. 2020;29(12):747-754. DOI: 10.1089/ scd.2020.0080.

6. Aflatoonian B, Ahrlund-Richter L, Amit M, Andrews PW, Beighton G, Bello PA, Benvenisty N, Berry LS, Bevan S, Blum B, Brooking J, Chen KG, Choo AB, Churchill GA, Corbel M, Damjanov I, Draper JS, Dvorak P, Emanuelsson K, Fleck RA, Ford A, Gertow K, Gertsenstein M, Gokhale PJ, Hamilton RS, Hampl A, Healy LE, Hovatta O, Hyllner J, Imreh MP, Itskovitz-Eldor J, Jackson J, Johnson JL, Jones M, Kee K, King BL, Knowles BB, Lako M, Lebrin F, Mallon BS, Manning D, Mayshar Y, McKay RD, Michalska AE, Mikkola M, Mileikovsky M, Minger SL, Moore HD, Mummery CL, Nagy A, Nakatsuji N, O’Brien CM, Oh SK, Olsson C, Otonkoski T, Park KY Passier R, Patel H, Patel M, Pedersen R, Pera MF, Piekarczyk MS, Pera RA, Reubinoff BE, Robins AJ, Rossant J, Rugg-Gunn P, Schulz TC, Semb H, Sherrer ES, Siemen H, Stacey GN, Stojkovic M, Suemori H, Szatkiewicz J, Turetsky T, Tuuri T, van den Brink S, Vintersten K, Vuoristo S, Ward D, Weaver TA, Young LA, Zhang W. Characterization of human embryonic stem cell lines by the International Stem Cell Initiative. Nat Biotechnol. 2007;25(7):803-16. DOI: 10.1038/nbt1318.

7. Gao X, Nowak-Imialek M, Chen X, Chen D, Herrmann D, Ruan D, Chen ACH, Eckersley-Maslin MA, Ahmad S, Lee YL, Kobayashi T, Ryan D, Zhong J, Zhu J, Wu J, Lan G, Petkov S, Yang J, Antunes L, Campos LS, Fu B, Wang S, Yong Y, Wang X, Xue SG, Ge L, Liu Z, Huang Y, Nie T, Li P, Wu D, Pei D, Zhang Y, Lu L, Yang F, Kimber SJ, Reik W, Zou X, Shang Z, Lai L, Surani A, Tam PPL, Ahmed A, Yeung WSB, Teichmann SA, Niemann H, Liu P. Establishment of porcine and human expanded potential stem cells. Nat Cell Biol. 2019;21(6):687-699. DOI: 10.1038/s41556-019-0333-2.

8. Menasché P, Vanneaux V, Hagège A, Bel A, Cholley B, Parouchev A, Cacciapuoti I, Al-Daccak R, Benhamouda N, Blons H, Agbulut O, Tosca L, Trouvin JH, Fabreguettes JR, Bellamy V, Charron D, Tartour E, Tachdjian G, Desnos M, Larghero J. Transplantation of Human Embryonic Stem Cell-Derived Cardiovascular Progenitors for Severe Ischemic Left Ventricular Dysfunction. J Am Coll Cardiol. 2018;71(4):429-438. DOI: 10.1016/j.jacc.2017.11.047

9. Zhou S, Flamier A, Abdouh M, Tétreault N, Barabino A, Wadhwa S, Bernier G. Differentiation of human embryonic stem cells into cone photoreceptors through simultaneous inhibition of BMP, TGF $\beta$ and Wnt signaling. Development. 2015;142(19):3294-306. DOI: 10.1242/dev.125385.

10. Hentze H, Soong PL, Wang ST, Phillips BW, Putti TC, Dunn NR. Teratoma formation by human embryonic stem cells: evaluation of essential parameters for future safety studies. Stem Cell Res. 2009;2(3):198-210. DOI: $10.1016 /$ j.scr.2009.02.002

11. Ratajczak MZ, Zuba-Surma E, Kucia M, Reca R, Wojakowski W, Ratajczak J. The pleiotropic effects of the SDF-1-CXCR4 axis in organogene- sis, regeneration and tumorigenesis. Leukemia. 2006;20(11):1915-24. DOI: $10.1038 /$ sj.leu.2404357.

12. Dominici M, Le Blanc K, Mueller I, Slaper-Cortenbach I, Marini F, Krause D, Deans R, Keating A, Prockop Dj, Horwitz E. Minimal criteria for defining multipotent mesenchymal stromal cells. The International Society for Cellular Therapy position statement. Cytotherapy. 2006;8(4):315-7. DOI: $10.1080 / 14653240600855905$.

13. Wagner W, Wein F, Seckinger A, Frankhauser M, Wirkner U, Krause U, Blake J, Schwager C, Eckstein V, Ansorge W, Ho AD. Comparative characteristics of mesenchymal stem cells from human bone marrow, adipose tissue, and umbilical cord blood. Exp Hematol. 2005;33(11):1402-16. DOI: $10.1016 /$ j.exphem.2005.07.003

14. Wang HS, Hung SC, Peng ST, Huang CC, Wei HM, Guo YJ, Fu YS, Lai MC Chen CC. Mesenchymal stem cells in the Wharton's jelly of the human umbilical cord. Stem Cells. 2004;22(7):1330-7. DOI: 10.1634/ stemcells.2004-0013.

15. Mushahary D, Spittler A, Kasper C, Weber V, Charwat V. Isolation, cultivation, and characterization of human mesenchymal stem cells. Cytometry A. 2018;93(1):19-31. DOI: 10.1002/cyto.a.23242.

16. Ginis I, Luo Y, Miura T, Thies S, Brandenberger R, Gerecht-Nir S, Amit M, Hoke A, Carpenter MK, Itskovitz-Eldor J, Rao MS. Differences between human and mouse embryonic stem cells. Dev Biol. 2004;269(2):36080. DOI: $10.1016 /$ j.ydbio.2003.12.034.

17. Tesar PJ, Chenoweth JG, Brook FA, Davies TJ, Evans EP, Mack DL, Gardner RL, McKay RD. New cell lines from mouse epiblast share defining features with human embryonic stem cells. Nature. 2007;448(7150):1969. DOI: $10.1038 /$ nature 05972.

18. Evans MJ, Kaufman MH. Establishment in culture of pluripotential cells from mouse embryos. Nature. 1981;292(5819):154-6. DOI $10.1038 / 292154 \mathrm{a} 0$.

19. Tian L, Zhu W, Liu Y, Gong Y, Lv A, Wang Z, Ding X, Li S, Fu Y, Lin Y, Yan Y. Neural Stem Cells Transfected with Leukemia Inhibitory Factor Promote Neuroprotection in a Rat Model of Cerebral Ischemia. Neurosci Bull. 2019;35(5):901-908. DOI: 10.1007/s12264-019-00405-5.

20. Gugliandolo A, Bramanti P, Mazzon E. Mesenchymal stem cell therapy in Parkinson's disease animal models. Curr Res Transl Med. 2017;65(2):51-60. DOI: 10.1016/j.retram.2016.10.007

21. Zarei-Kheirabadi M, Sadrosadat $H$, Mohammadshirazi A, Jaberi R, Sorouri F, Khayyatan F, Kiani S. Human embryonic stem cell-derived neura stem cells encapsulated in hyaluronic acid promotes regeneration in a contusion spinal cord injured rat. Int J Biol Macromol. 2020;148:1118 1129. DOI: $10.1016 / \mathrm{j}$. ijbiomac.2020.01.219.

22. Izrael M, Slutsky SG, Admoni T, Cohen L, Granit A, Hasson A, Itskovitz-Eldor J, Krush Paker L, Kuperstein G, Lavon N, Yehezkel Ionescu S, Solmesky LJ, Zaguri R, Zhuravlev A, Volman E, Chebath J, Revel M. Safety and efficacy of human embryonic stem cell-derived astrocytes following intrathecal transplantation in SOD1G93A and NSG animal models. Stem Cell Res Ther. 2018;9(1):152. DOI: 10.1186/s13287-018-0890-5.

23. Hirsch T, Rothoeft T, Teig N, Bauer JW, Pellegrini G, De Rosa L, Scaglion D, Reichelt J, Klausegger A, Kneisz D, Romano O, Secone Seconetti A, Contin R, Enzo E, Jurman I, Carulli S, Jacobsen F, Luecke T, Lehnhardt M, Fischer M, Kueckelhaus M, Quaglino D, Morgante M, Bicciato S, Bondanza S, De Luca M. Regeneration of the entire human epidermis using transgenic stem cells. Nature. 2017;551(7680):327-332. DOI 10.1038 /nature24487.

24. Yang J, Zhang YS, Yue K, Khademhosseini A. Cell-laden hydrogels for osteochondral and cartilage tissue engineering. Acta Biomater 2017;57:1-25. DOI: 10.1016/j.actbio.2017.01.036

25. Haleem A, Javaid M, Khan RH, Suman R. 3D printing applications in bone tissue engineering. J Clin Orthop Trauma. 2020;11(Suppl 1):S118-S124. DOI: 10.1016/j.jcot.2019.12.002.

26. Sorkio A, Koch L, Koivusalo L, Deiwick A, Miettinen S, Chichkov B, Skottman H. Human stem cell based corneal tissue mimicking structures using laser-assisted 3D bioprinting and functional bioinks. Biomaterials. 2018;171:57-71. DOI: 10.1016/j.biomaterials.2018.04.034

27. Smith A. A glossary for stem-cell biology. Nature. 2006; 144(7097):1060-1060. DOI: $10.1038 /$ nature 04954

28. Briggs R, King TJ. Transplantation of Living Nuclei From Blastula Cells into Enucleated Frogs' Eggs. Proc Natl Acad Sci U S A. 1952;38(5):45563. DOI: $10.1073 /$ pnas.38.5.455

29. Martin GR. Isolation of a pluripotent cell line from early mouse embryos cultured in medium conditioned by teratocarcinoma stem cells. Proc Natl Acad Sci U S A. 1981;78(12):7634-8. DOI: 10.1073/ pnas.78.12.7634

30. Gurdon JB, Laskey RA, Reeves OR. The developmental capacity of nuclei transplanted from keratinized skin cells of adult frogs. J Embryol Exp Morphol. 1975;34(1):93-112. 
31. Zhong W, Jiang MM, Weinmaster G, Jan LY, Jan YN. Differential expression of mammalian Numb, Numblike and Notch1 suggests distinct roles during mouse cortical neurogenesis. Development. 1997;124(10):1887-97.

32. Lee HS, Crane GG, Merok JR, Tunstead JR, Hatch NL, Panchalingam K, Powers MJ, Griffith LG, Sherley JL. Clonal expansion of adult rat hepatic stem cell lines by suppression of asymmetric cell kinetics (SACK). Biotechnol Bioeng. 2003;83(7):760-71. DOI: 10.1002/bit.10727.

33. Benz C, Copley MR, Kent DG, Wohrer S, Cortes A, Aghaeepour N, Ma E, Mader H, Rowe K, Day C, Treloar D, Brinkman RR, Eaves CJ. Hematopoietic stem cell subtypes expand differentially during development and display distinct lymphopoietic programs. Cell Stem Cell. 2012;10(3):273-83. DOI: 10.1016/j.stem.2012.02.007.

34. Kolios G, Moodley Y. Introduction to stem cells and regenerative medicine. Respiration. 2013;85(1):3-10. DOI: 10.1159/000345615.

35. Bogdan P, Deasy BM, Gharaibeh B, Roehrs T, Marculescu R. Heterogeneous structure of stem cells dynamics: statistical models and quantitative predictions. Sci Rep. 2014;4:4826. DOI: 10.1038/srep04826.

36. Evano B, Khalilian S, Le Carrou G, Almouzni G, Tajbakhsh S. Dynamics of Asymmetric and Symmetric Divisions of Muscle Stem Cells In Vivo and on Artificial Niches. Cell Rep. 2020;30(10):3195-3206.e7. DOI 10.1016/j.celrep.2020.01.097.

37. Komarova NL. Principles of regulation of self-renewing cell lineages PLoS One. 2013;8(9):e72847. DOI: 10.1371/journal.pone.0072847.

38. Lu P, Takai K, Weaver VM, Werb Z. Extracellular matrix degradation and remodeling in development and disease. Cold Spring Harb Perspect Biol. 2011;3(12):a005058. DOI: 10.1101/cshperspect.a005058.

39. Lozoya OA, Gilchrist CL, Guilak F. Universally Conserved Relationships between Nuclear Shape and Cytoplasmic Mechanical Properties in Human Stem Cells. Sci Rep. 2016;6:23047. DOI: 10.1038/srep23047.

40. McColloch A, Rabiei M, Rabbani P, Bowling A, Cho M. Correlation between Nuclear Morphology and Adipogenic Differentiation: Application of a Combined Experimental and Computational Modeling Approach. Sci Rep. 2019;9(1):16381. DOI: 10.1038/s41598-019-52926-8.

41. Cook D, Genever P. Regulation of mesenchymal stem cell differentiation. Adv Exp Med Biol. 2013;786:213-29. DOI: 10.1007/978-94-007-6621-1_12.

42. Villa-Diaz LG, Kim JK, Laperle A, Palecek SP, Krebsbach PH. Inhibition of Focal Adhesion Kinase Signaling by Integrin $\alpha 6 \beta 1$ Supports Human Pluripotent Stem Cell Self-Renewal. Stem Cells. 2016;34(7):1753-64 DOI: $10.1002 /$ stem.2349.

43. Foster LJ, Zeemann PA, Li C, Mann M, Jensen ON, Kassem M. Differential expression profiling of membrane proteins by quantitative proteomics in a human mesenchymal stem cell line undergoing osteoblast differentiation. Stem Cells. 2005;23(9):1367-77. DOI: 10.1634/ stemcells.2004-0372.

44. Pattappa G, Heywood HK, de Bruijn JD, Lee DA. The metabolism of human mesenchymal stem cells during proliferation and differentiation. Cell Physiol. 2011;226(10):2562-70. DOI: 10.1002/jcp.22605.

45. Mylotte LA, Duffy AM, Murphy M, O'Brien T, Samali A, Barry F, Szegezdi E. Metabolic flexibility permits mesenchymal stem cell survival in an ischemic environment. Stem Cells. 2008;26(5):1325-36. DOI: 10.1634/ stemcells.2007-1072.

46. Rémy M, Ferraro F, Le Salver P, Rey S, Genot E, Djavaheri-Mergny M, Thébaud N, Boiziau C, Boeuf H. Isolation and Culture of Human Stem Cells from Apical Papilla under Low Oxygen Concentration Highlight Original Properties. Cells. 2019;8(12):1485. DOI: 10.3390/cells8121485.

47. Millman JR, Tan JH, Colton CK. The effects of low oxygen on self-renewal and differentiation of embryonic stem cells. Curr Opin Organ Transplant. 2009;14(6):694-700. DOI: 10.1097/MOT.0b013e3283329d53.

48. Ho TT, Warr MR, Adelman ER, Lansinger OM, Flach J, Verovskaya EV, Figueroa ME, Passegué E. Autophagy maintains the metabolism and function of young and old stem cells. Nature. 2017;543(7644):205210. DOI: $10.1038 /$ nature21388.

49. Casares-Crespo L, Calatayud-Baselga I, García-Corzo L, Mira H. On the Role of Basal Autophagy in Adult Neural Stem Cells and Neurogenesis Front Cell Neurosci. 2018;12:339. DOI: 10.3389/fncel.2018.00339.

50. Boya P, Codogno P, Rodriguez-Muela N. Autophagy in stem cells: repair, remodelling and metabolic reprogramming. Development. 2018;145(4):dev146506. DOI: 10.1242/dev.146506.

51. Thompson S, Stern PL, Webb M, Walsh FS, Engstrom W, Evans EP, Shi WK, Hopkins B, Graham CF. Cloned human teratoma cells differentiate into neuron-like cells and other cell types in retinoic acid. J Cell Sci. 1984;72:37-64.

52. Cinkornpumin JK, Kwon SY, Guo Y, Hossain I, Sirois J, Russett CS, Tseng HW, Okae H, Arima T, Duchaine TF, Liu W, Pastor WA. Naive Human Embryonic Stem Cells Can Give Rise to Cells with a Trophoblast-like
Transcriptome and Methylome. Stem Cell Reports. 2020 15(1):198213. DOI: $10.1016 /$ j.stemcr.2020.06.003.

53. Kucharzewski M, Rojczyk E, Wilemska-Kucharzewska K, Wilk R, Hudecki J, Los MJ. Novel trends in application of stem cells in skin wound healing. Eur J Pharmacol. 2019;843:307-315. DOI: 10.1016/j. ejphar.2018.12.012

54. Fang J, Guo Y, Tan S, Li Z, Xie H, Chen P, Wang K, He Z, He P, Ke Y, Jiang $\mathrm{X}$, Chen Z. Autologous Endothelial Progenitor Cells Transplantation for Acute Ischemic Stroke: A 4-Year Follow-Up Study. Stem Cells Transl Med. 2019;8(1):14-21. DOI: 10.1002/sctm.18-0012.

55. Guerin CL, Loyer X, Vilar J, Cras A, Mirault T, Gaussem P, Silvestre JS, Smadja DM. Bone-marrow-derived very small embryonic-like stem cells in patients with critical leg ischaemia: evidence of vasculogenic potential. Thromb Haemost. 2015;113(5):1084-94. DOI: 10.1160/ TH14-09-0748.

56. Fomekong E, Dufrane D, Berg BV, André W, Aouassar N, Veriter S, Raftopoulos C. Application of a three-dimensional graft of autologous osteodifferentiated adipose stem cells in patients undergoing minimally invasive transforaminal lumbar interbody fusion: clinical proof of concept. Acta Neurochir (Wien). 2017;159(3):527-536. DOI: 10.1007/ s00701-016-3051-6.

57. Chen Z, Wang Y, Shi C. Therapeutic Implications of Newly Identified Stem Cell Populations From the Skin Dermis. Cell Transplant. 2015;24(8):1405-22. DOI: 10.3727/096368914X682431.

58. Blanpain C, Lowry WE, Geoghegan A, Polak L, Fuchs E. Self-renewal, multipotency, and the existence of two cell populations within an epithelial stem cell niche. Cell. 2004;118(5):635-48. DOI: 10.1016/j. cell.2004.08.012

59. Sangwan VS, Basu S, MacNeil S, Balasubramanian D. Simple limbal epithelial transplantation (SLET): a novel surgical technique for the treatment of unilateral limbal stem cell deficiency. Br J Ophthalmol. 2012;96(7):931-4. DOI: 10.1136/bjophthalmol-2011-301164.

60. Gronthos S, Mankani M, Brahim J, Robey PG, Shi S. Postnatal human dental pulp stem cells (DPSCs) in vitro and in vivo. Proc Natl Acad Sci U S A. 2000;97(25):13625-30. DOI: 10.1073/pnas.240309797.

61. Nakashima M, Iohara K, Murakami M, Nakamura H, Sato Y, Ariji Y, Matsushita K. Pulp regeneration by transplantation of dental pulp stem cells in pulpitis: a pilot clinical study. Stem Cell Res Ther. 2017;8(1):61. DOI: $10.1186 / \mathrm{s} 13287-017-0506-5$

62. Seo BM, Miura M, Gronthos S, Bartold PM, Batouli S, Brahim J, Young M, Robey PG, Wang CY, Shi S. Investigation of multipotent postnatal stem cells from human periodontal ligament. Lancet. 2004;364(9429):14955. DOI: $10.1016 /$ S0140-6736(04)16627-0.

63. Murrell W, Féron F, Wetzig A, Cameron N, Splatt K, Bellette B, Bianco J, Perry C, Lee G, Mackay-Sim A. Multipotent stem cells from adult olfactory mucosa. Dev Dyn. 2005:233(2):496-515. DOI: 10.1002/dvdy.20360.

64. Guan JJ, Niu X, Gong FX, Hu B, Guo SC, Lou YL, Zhang CQ, Deng ZF, Wang $Y$. Biological characteristics of human-urine-derived stem cells: potential for cell-based therapy in neurology. Tissue Eng Part A. 2014;20(1314):1794-806. DOI: 10.1089/ten.TEA.2013.0584.

65. Miao Z, Jin J, Chen L, Zhu J, Huang W, Zhao J, Qian H, Zhang X. Isolation of mesenchymal stem cells from human placenta: comparison with human bone marrow mesenchymal stem cells. Cell Biol Int 2006;30(9):681-7. DOI: 10.1016/j.cellbi.2006.03.009.

66. Deng Y, Zhang Y, Ye L, Zhang T, Cheng J, Chen G, Zhang Q, Yang Y. Umbilical Cord-derived Mesenchymal Stem Cells Instruct Monocytes Towards an IL10-producing Phenotype by Secreting IL6 and HGF. Sci Rep. 2016;6:37566. DOI: 10.1038/srep37566.

67. Arno AI, Amini-Nik S, Blit PH, Al-Shehab M, Belo C, Herer E, Tien $\mathrm{CH}_{\text {, }}$ Jeschke MG. Human Wharton's jelly mesenchymal stem cells promote skin wound healing through paracrine signaling. Stem Cell Res Ther 2014;5(1):28. DOI: $10.1186 /$ scrt417.

68. De Coppi P, Bartsch G Jr, Siddiqui MM, Xu T, Santos CC, Perin L, Mostoslavsky G, Serre AC, Snyder EY, Yoo JJ, Furth ME, Soker S, Atala A. Isolation of amniotic stem cell lines with potential for therapy. Nat Biotechnol. 2007;25(1):100-6. DOI: 10.1038/nbt1274.

69. Liao N, Shi Y, Wang Y, Liao F, Zhao B, Zheng Y, Zeng Y, Liu X, Liu J. Antioxidant preconditioning improves therapeutic outcomes of adipose tissue-derived mesenchymal stem cells through enhancing intrahepatic engraftment efficiency in a mouse liver fibrosis model. Stem Cell Res Ther. 2020;11(1):237. DOI: 10.1186/s13287-020-01763-y.

70. Dai R, Yu Y, Yan G, Hou X, Ni Y, Shi G. Intratracheal administration of adipose derived mesenchymal stem cells alleviates chronic asthma in a mouse model. BMC Pulm Med. 2018;18(1):131. DOI: 10.1186/ s12890-018-0701-x.

71. Zanganeh E, Soudi S, Zavaran Hosseini A. Intralesional Injection of Mouse Mesenchymal Stem Cells Reduces IL-10 Production and Parasite 
Burden in L. major Infected BALB/c Mice. Cell J. 2020;22(Suppl 1):1118. DOI: $10.22074 /$ cellj.2020.6838.

72. de Mendonça L, Felix NS, Blanco NG, Da Silva JS, Ferreira TP, Abreu SC Cruz FF, Rocha N, Silva PM, Martins V, Capelozzi VL, Zapata-Sudo G, Rocco PRM, Silva PL. Mesenchymal stromal cell therapy reduces lung inflammation and vascular remodeling and improves hemodynamics in experimental pulmonary arterial hypertension. Stem Cell Res Ther 2017;8(1):220. DOI: 10.1186/s13287-017-0669-0.

73. Apostolou KG, Papanikolaou IG, Katselis C, Feretis T, Kletsas D, Konstadoulakis MM, Lymperi M, Saetta AA, Tsikalakis S, Agrogiannis G, Patsouris E, Zografos GC, Papalois AE. Undifferentiated Adipose Tissue Stem Cell Transplantation Promotes Hepatic Regeneration, Ameliorates Histopathologic Damage of the Liver, and Upregulates the Expression of Liver Regeneration- and Liver-Specific Genes in a Rat Model of Partial Hepatectomy. Stem Cells Int. 2018;2018:1393607. DOI: $10.1155 / 2018 / 1393607$

74. Wu X, Zhang S, Lai J, Lu H, Sun Y, Guan W. Therapeutic Potential of Bama Pig Adipose-Derived Mesenchymal Stem Cells for the Treatment of Carbon Tetrachloride-Induced Liver Fibrosis. Exp Clin Transplant. 2020;18(7):823-831. DOI: 10.6002/ect.2020.0108.

75. Zhang AJ, Jiang T, Li Q Jin PS, Tan Q. Experimental research on ADSCs-NCSS in wound repair. Exp Ther Med. 2018;16(6):4429-4436. DOI: 10.3892/etm.2018.6756

76. Xu W, Cheng W, Cui X, Xu G. Therapeutic effect against retinal neovascularization in a mouse model of oxygen-induced retinopathy: bone marrow-derived mesenchymal stem cells versus Conbercept. BMC Ophthalmol. 2020;20(1):7. DOI: 10.1186/s12886-019-1292-x.

77. Zhu C, Wang K, Chen Z, Han Y, Chen H, Li Q, Liu Z, Qian L, Tang J, Shen H. Antinociceptive effect of intrathecal injection of miR-9-5p modified mouse bone marrow mesenchymal stem cells on a mouse model of bone cancer pain. J Neuroinflammation. 2020;17(1):85. DOI: 10.1186/ s12974-020-01765-w.

78. Yao Z, Liu H, Yang M, Bai Y, Zhang B, Wang C, Yan Z, Niu G, Zou Y, Li Y. Bone marrow mesenchymal stem cell-derived endothelial cell increase capillary density and accelerate angiogenesis in mouse hindlimb ischemia model. Stem Cell Res Ther. 2020;11(1):221. DOI: 10.1186/s13287-020-01710-x.

79. Khalil MR, El-Demerdash RS, Elminshawy HH, Mehanna ET, Mesbah NM, Abo-Elmatty DM. Therapeutic effect of bone marrow mesenchymal stem cells in a rat model of carbon tetrachloride induced liver fibrosis. Biomed J. 2020;S2319-4170(20)30048-2. DOI: 10.1016/j.bj.2020.04.011.

80. Bingham JR, Kniery KR, Jorstad NL, Horkayne-Szakaly I, Hoffer ZS, Salgar SK. "Stem cell therapy to promote limb function recovery in peripheral nerve damage in a rat model" - Experimental research. Ann Med Surg (Lond). 2019;41:20-28. DOI: 10.1016/j.amsu.2019.03.009.

81. Yan J, Liang J, Cao Y, El Akkawi MM, Liao X, Chen X, Li C, Li K, Xie G, Liu H. Efficacy of topical and systemic transplantation of mesenchymal stem cells in a rat model of diabetic ischemic wounds. Stem Cell Res Ther 2021;12(1):220. DOI: 10.1186/s13287-021-02288-8.

82. Kan XL, Pan XH, Zhao J, He J, Cai XM, Pang RQ, Zhu XQ, Cao XB, Ruan GP. Effect and mechanism of human umbilical cord mesenchymal stem cells in treating allergic rhinitis in mice. Sci Rep. 2020;10(1):19295. DOI: $10.1038 / s 41598-020-76343-4$.

83. Li X, Lu C, Fan D, Lu X, Xia Y, Zhao H, Xu H, Zhu Y, Li J, Liu H, Xiao C. Human Umbilical Mesenchymal Stem Cells Display Therapeutic Potentia in Rheumatoid Arthritis by Regulating Interactions Between Immunity and Gut Microbiota via the Aryl Hydrocarbon Receptor. Front Cell Dev Biol. 2020;8:131. DOI: 10.3389/fcell.2020.00131.

84. Yea JH, Park JK, Kim IJ, Sym G, Bae TS, Jo CH. Regeneration of a full-thickness defect of rotator cuff tendon with freshly thawed umbilical cord-derived mesenchymal stem cells in a rat model. Stem Cell Res Ther. 2020;11(1):387. DOI: 10.1186/s13287-020-01906-1.

85. Li J, Yu Q, Huang H, Deng W, Cao X, Adu-Frimpong M, Yu J, Xu X. Human chorionic plate-derived mesenchymal stem cells transplantation restores ovarian function in a chemotherapy-induced mouse mode of premature ovarian failure. Stem Cell Res Ther. 2018;9(1):81. DOI: 10.1186/s13287-018-0819-z

86. Li J, Xu SQ Zhang K, Zhang WJ, Liu HL, Xu Z, Li H, Lou JN, Ge LH, Xu BH. Treatment of gingival defects with gingival mesenchymal stem cells derived from human fetal gingival tissue in a rat model. Stem Cell Res Ther. 2018;9(1):27. DOI: 10.1186/s13287-017-0751-7.

87. Motawea SM, Noreldin RI, Naguib YM. Potential therapeutic effects of endothelial cells trans-differentiated from Wharton's Jelly-derive mesenchymal stem cells on altered vascular functions in aged diabetic rat model. Diabetol Metab Syndr. 2020;12:40. DOI: 10.1186/ s13098-020-00546-y.

88. Prahasanti C, Subrata LH, Saskianti T, Suardita K, Ernawati DS. Combined Hydroxyapatite Scaffold and Stem Cell from Human Exfoliated
Deciduous Teeth Modulating Alveolar Bone Regeneration via Reg ulating Receptor Activator of Nuclear Factor-Kb and Osteoprotegerin System. Iran J Med Sci. 2019;44(5):415-421. DOI: 10.30476/ IJMS.2019.44962

89. Stevens LC, Little CC. Spontaneous Testicular Teratomas in an Inbred Strain of Mice. Proc Natl Acad Sci U S A. 1954:40(11):1080-7. DOI: 10.1073/pnas.40.11.1080

90. Kleinsmith LJ, Pierce GB Jr. Multipotentiality of single embryonal carcinoma cells. Cancer Res. 1964;24:1544-51.

91. Martin GR, Evans MJ. The morphology and growth of a pluripotent teratocarcinoma cell line and its derivatives in tissue culture. Cell. 1974;2(3):163-72. DOI: 10.1016/0092-8674(74)90090-7.

92. Solter D. From teratocarcinomas to embryonic stem cells and beyond: a history of embryonic stem cell research. Nat Rev Genet. 2006;7(4):31927. DOI: $10.1038 / \mathrm{nrg} 1827$.

93. Brinster RL. The effect of cells transferred into the mouse blastocys on subsequent development. J Exp Med. 1974;140(4):1049-56. DOI 10.1084/jem.140.4.1049.

94. Smith A. Pluripotent stem cells: private obsession and public expectation. EMBO Mol Med. 2010;2(4):113-6. DOI: 10.1002/ emmm.201000065.

95. Shamblott MJ, Axelman J, Wang S, Bugg EM, Littlefield JW, Donovan PJ, Blumenthal PD, Huggins GR, Gearhart JD. Derivation of pluripotent stem cells from cultured human primordial germ cells. Proc Natl Acad Sci U S A. 1998;95(23):13726-31. DOI: 10.1073/pnas.95.23.13726.

96. Klimanskaya I, Chung Y, Becker S, Lu SJ, Lanza R. Human em bryonic stem cell lines derived from single blastomeres. Nature. 2006;444(7118):481-5. DOI: 10.1038/nature05142.

97. Zhang X, Stojkovic P, Przyborski S, Cooke M, Armstrong L, Lako M, Stojkovic M. Derivation of human embryonic stem cells from developing and arrested embryos. Stem Cells. 2006;24(12):2669-76. DOI: 10.1634/stemcells.2006-0377.

98. Mai Q, Yu Y, Li T, Wang L, Chen MJ, Huang SZ, Zhou C, Zhou Q. Derivation of human embryonic stem cell lines from parthenogenetic blastocysts. Cell Res. 2007;17(12):1008-19. DOI: 10.1038/cr.2007.102.

99. Pan G, Thomson JA. Nanog and transcriptional networks in embryonic stem cell pluripotency. Cell Res. 2007;17(1):42-9. DOI: 10.1038/ sj.cr.7310125.

100. Pan G, Li J, Zhou Y, Zheng H, Pei D. A negative feedback loop of transcription factors that controls stem cell pluripotency and self-renewal. FASEB J. 2006;20(10):1730-2. DOI: 10.1096/fj.05-5543fje.

101. Cieślar-Pobuda A, Knoflach V, Ringh MV, Stark J, Likus W, Siemianowicz K, Ghavami S, Hudecki A, Green JL, Łos MJ. Transdifferentiation and reprogramming: Overview of the processes, their similarities and differences. Biochim Biophys Acta Mol Cell Res. 2017;1864(7):1359-1369. DOI: 10.1016/j.bbamcr.2017.04.017.

102. Zhou Q Brown J, Kanarek A, Rajagopal J, Melton DA. In vivo reprogramming of adult pancreatic exocrine cells to beta-cells. Nature. 2008:455(7213):627-32. DOI: 10.1038/nature07314.

103. Nam YJ, Song K, Luo X, Daniel E, Lambeth K, West K, Hill JA, DiMaio JM, Baker LA, Bassel-Duby R, Olson EN. Reprogramming of human fibroblasts toward a cardiac fate. Proc Natl Acad Sci U S A. 2013;110(14):5588-93. DOI: 10.1073/pnas.1301019110.

104. Gjerde C, Mustafa K, Hellem S, Rojewski M, Gjengedal H, Yassin MA Feng X, Skaale S, Berge T, Rosen A, Shi XQ, Ahmed AB, Gjertsen BT, Schrezenmeier H, Layrolle P. Cell therapy induced regeneration of severely atrophied mandibular bone in a clinical trial. Stem Cell Res Ther 2018;9(1):213. DOI: 10.1186/s13287-018-0951-9.

105. Samberg M, Stone R 2nd, Natesan S, Kowalczewski A, Becerra S, Wrice $\mathrm{N}$, Cap A, Christy R. Platelet rich plasma hydrogels promote in vitro and in vivo angiogenic potential of adipose-derived stem cells. Acta Biomater. 2019;87:76-87. DOI: 10.1016/j.actbio.2019.01.039.

106. Moon KC, Suh HS, Kim KB, Han SK, Young KW, Lee JW, Kim MH. Potentia of Allogeneic Adipose-Derived Stem Cell-Hydrogel Complex for Treating Diabetic Foot Ulcers. Diabetes. 2019;68(4):837-846. DOI: 10.2337/ db18-0699.

107. Jia Y, Shi X, Xie Y, Xie X, Wang Y, Li S. Human umbilical cord stem cell conditioned medium versus serum-free culture medium in the treatment of cryopreserved human ovarian tissues in in-vitro culture: a randomized controlled trial. Stem Cell Res Ther. 2017;8(1):152. DOI: 10.1186/s13287-017-0604-4

108. Gupta PK, Chullikana A, Rengasamy M, Shetty N, Pandey V, Agarwal V, Wagh SY, Vellotare PK, Damodaran D, Viswanathan P, Thej C, Balasubramanian S, Majumdar AS. Efficacy and safety of adult human bone marrow-derived, cultured, pooled, allogeneic mesenchymal stroma cells (Stempeucel@): preclinical and clinical trial in osteoarthritis of the knee joint. Arthritis Res Ther. 2016;18(1):301. DOI: 10.1186/ s13075-016-1195-7. 
109. Lamo-Espinosa JM, Mora G, Blanco JF, Granero-Moltó F, Nuñez-Córdoba JM, Sánchez-Echenique C, Bondía JM, Aquerreta JD, Andreu EJ, Ornilla E, Villarón EM, Valentí-Azcárate A, Sánchez-Guijo F, Del Cañizo MC, Valentí-Nin JR, Prósper F. Intra-articular injection of two different doses of autologous bone marrow mesenchymal stem cells versus hyaluronic acid in the treatment of knee osteoarthritis: multicenter randomized controlled clinical trial (phase I/II). J Transl Med. 2016;14(1):246. DOI: 10.1186/s12967-016-0998-2.

110. Bartolucci J, Verdugo FJ, González PL, Larrea RE, Abarzua E, Goset C, Rojo P, Palma I, Lamich R, Pedreros PA, Valdivia G, Lopez VM, Nazzal C, Alcayaga-Miranda F, Cuenca J, Brobeck MJ, Patel AN, Figueroa FE, Khoury M. Safety and Efficacy of the Intravenous Infusion of Umbilical Cord Mesenchymal Stem Cells in Patients With Heart Failure: A Phase 1/2 Randomized Controlled Trial (RIMECARD Trial [Randomized Clinical Trial of Intravenous Infusion Umbilical Cord Mesenchymal Stem Cells on Cardiopathy]). Circ Res. 2017;121(10):1192-1204. DOI: 10.1161/CIRCRESAHA.117.310712.

111. Soetisna TW, Sukmawan R, Setianto B, Mansyur M, Murni TW, Listiyaningsih E, Santoso A. Combined transepicardial and transseptal implantation of autologous CD 133+ bone marrow cells during bypass grafting improves cardiac function in patients with low ejection fraction. J Card Surg. 2020;35(4):740-746. DOI: 10.1111/jocs.14454.

112. Oh KW, Moon C, Kim HY, Oh SI, Park J, Lee JH, Chang IY, Kim KS, Kim SH Phase I trial of repeated intrathecal autologous bone marrow-derived mesenchymal stromal cells in amyotrophic lateral sclerosis. Stem Cells Transl Med. 2015;4(6):590-7. DOI: 10.5966/sctm.2014-0212.

113. Syková E, Rychmach P, Drahorádová I, Konrádová Š, Růžičková K, Voř́šsek I, Forostyak S, Homola A, Bojar M. Transplantation of Mesenchymal Stromal Cells in Patients With Amyotrophic Lateral Sclerosis: Results of Phase I/IIa Clinical Trial. Cell Transplant. 2017;26(4):647658. DOI: $10.3727 / 096368916 X 693716$

114. Pang Y, Xiao HW, Zhang H, Liu ZH, Li L, Gao Y, Li HB, Jiang ZJ, Tan H, Lin JR, Du X, Weng JY, Nie DN, Lin DJ, Zhang XZ, Liu QF, Xu DR, Chen HJ, Ge XH, Wang XY, Xiao Y. Allogeneic Bone Marrow-Derived Mesenchymal Stromal Cells Expanded In Vitro for Treatment of Aplastic Anemia: A Multicenter Phase II Trial. Stem Cells Transl Med. 2017;6(7):15691575. DOI: $10.1002 / \mathrm{sctm} .16-0227$

115. Purev E, Tian X, Aue G, Pantin J, Vo P, Shalabi R, Reger RN, Cook Ramos C, Cho E, Worthy T, Khuu H, Stroncek D, Young NS, Childs RW Allogeneic transplantation using CD34+ selected peripheral blood progenitor cells combined with non-mobilized donor T cells for refractory severe aplastic anaemia. Br J Haematol. 2017;176(6):950-960. DOI: 10.1111/bjh.14448.

116. Leng Z, Zhu R, Hou W, Feng Y, Yang Y, Han Q, Shan G, Meng F, Du D, Wang S, Fan J, Wang W, Deng L, Shi H, Li H, Hu Z, Zhang F, Gao J, Liu H, Li X, Zhao Y, Yin K, He X, Gao Z, Wang Y, Yang B, Jin R, Stambler I, Lim LW, Su H, Moskalev A, Cano A, Chakrabarti S, Min KJ, Ellison-Hughes G, Caruso C, Jin K, Zhao RC. Transplantation of ACE2- Mesenchymal Stem Cells Improves the Outcome of Patients with COVID-19 Pneumonia. Aging Dis. 2020;11(2):216-228. DOI: 10.14336/AD.2020.0228.

117. Dhere T, Copland I, Garcia M, Chiang KY, Chinnadurai R, Prasad M, Galipeau J, Kugathasan S. The safety of autologous and metabolically fit bone marrow mesenchymal stromal cells in medically refractory Crohn's disease - a phase 1 trial with three doses. Aliment Pharmaco Ther. 2016;44(5):471-81. DOI: 10.1111/apt.13717.

118. Zhang J, Lv S, Liu X, Song B, Shi L. Umbilical Cord Mesenchymal Stem Cell Treatment for Crohn's Disease: A Randomized Controlled Clinical Trial. Gut Liver. 2018;12(1):73-78. DOI: 10.5009/gnl17035.

119. Zhao K, Lou R, Huang F, Peng Y, Jiang Z, Huang K, Wu X, Zhang Y, Fan Z, Zhou H, Liu C, Xiao Y, Sun J, Li Y, Xiang P, Liu Q. Immunomodulation effects of mesenchymal stromal cells on acute graft-versus-host disease after hematopoietic stem cell transplantation. Biol Blood Marrow Transplant. 2015;21(1):97-104. DOI: 10.1016/j.bbmt.2014.09.030.

120. Wang X, Zhang M, He P. Pre-infusion single-dose mesenchymal stem cells promote platelet engraftment and decrease severe acute graft versus host disease without relapse in haploidentical peripheral blood stem cell transplantation. J Int Med Res. 2020;48(5):300060520920438. DOI: $10.1177 / 0300060520920438$.

121. Carlsson PO, Schwarcz E, Korsgren O, Le Blanc K. Preserved $\beta$-cell function in type 1 diabetes by mesenchymal stromal cells. Diabetes. 2015;64(2):587-92. DOI: 10.2337/db14-0656.

122. Delgado E, Perez-Basterrechea M, Suarez-Alvarez B, Zhou H, Revuelta EM, Garcia-Gala JM, Perez S, Alvarez-Viejo M, Menendez E, Lopez-Larrea C, Tang R, Zhu Z, Hu W, Moss T, Guindi E, Otero J, Zhao Y. Modulation of Autoimmune T-Cell Memory by Stem Cell Educator Therapy: Phase 1/2 Clinical Trial. EBioMedicine. 2015;2(12):2024-36. DOI: 10.1016/j. ebiom.2015.11.003. 